\title{
Different perspectives in defining culture
}

\author{
Adelia Hanny Rachman \\ Department of Anthropology \\ Faculty of Cultural Sciences, Universitas Gadjah Mada \\ Address: Bulaksumur, Yogyakarta, Indonesia - 55281 \\ E-mail: adelia@alumni.ui.ac.id
}

\begin{abstract}
Society grows and develops rapidly while the theory of culture itself in Indonesia mostly refers to Koentjaraningrat's paradigm. His theory is basically general and commonly used as a basic examination. The fact concerns me due to its deficiency - less relevant to accommodate currently cultural development. To answer this problem, I pertain to the Ahimsa-Putra's cultural theory. He proposed his thoughts to a more specific concept of culture. In his article entitled Mendefinisikan Kembali Kebudayaan, Ahimsa-Putra not merely describes definition of culture yet along with its dimensions and elements. This review would like to show whether his theory possibly can stipulate an answer to his criticism towards Koentjaraningrat's theory. Later on, I shall offer my disagreements in some of his views.
\end{abstract}

Keywords: Ahimsa-Putra; cultural concept; culture; definition; social science

Article History

Received: September 14, $2021 \quad$ Accepted: October 25, 2021

Cite this as: Rachman AH (2021) Different perspectives in defining culture. Indonesian Journal of Social Sciences 13 (2):84-94. DOI 10.20473/ijss.v13i2.29918.

\section{Introduction}

Humans and culture will everlastingly coexist. Culture has been inspired as an outcome of social construction which society influences the development of civilization. The goal leads to a certain point - traditional-simple to modern-complex-of times known as developmental theory. Lauer complemented his view on the theory of development, which was pioneered by Spencer and Durkheim, which stated progress means following the pattern of modernization whose pattern of change is constant and universal (Lauer 1973:458). The change will affect the culture by granting practical and theoretical implications. Therefore, critical reflection is needed to face socio-cultural phenomena in order to make a positive contribution. I question how relevant Ahimsa-Putra's new perspective is by perfecting the cultural concept of Koentjaraningrat in today's socio-cultural sciences. Here, Ahimsa-Putra's point of view is very interesting to review. This review of his article desire to present the new ideas he created and provide an overview of their relevance in current society.

\section{Methods}

The review was made referring to the article Mendefinisikan Kembali Kebudayaan by Heddy Shri Ahimsa-Putra in the Lembaran Antropologi Budaya, volume 2 no. 2 (2020), pp. 2-25, 46. Besides summarizing the content of Ahimsa-Putra, I would like to examine his offered notions regarding the redefinition of culture contained in his writing by certain discussions concerning theoretical perspectives on culture. Moreover, I would like to explore how the paradigm is relevant as a basis examination nowadays. In general, this paper summarizes the Ahimsa-Putra philosophical thoughts and provides crucial critical feedback against it and clarified with supporting arguments.

84 


\section{Results and Discussion}

The comprehension of each socio-cultural phenomenon is closely related to the basic understanding of culture which could be obtained from various paradigms. Ahimsa-Putra in his writings tries to provide a new philosophical view of culture and its attributes. At the beginning of his writing, Ahimsa-Putra quoted the definition of culture, as follows "Culture is the result of human creation, taste, and initiative." - he wrote this quote and claimed as a Ki Hadjar Dewantara's theoretical thought but it can be fallible to say so by reason of authorship of the theory is Djojodigoeno (Koentjaraningrat 2002:181). Meanwhile, Dewantara's opinion actually emphasizes the human mind's upshot as an outcome of struggling against the influence of time and nature (Pardimin et al. 2018:7). Djojodigoeno's opinion is admired for its level of abstraction thus it possibly reaches a wider scope of culture and is able to represent more perceptions about culture. Ahimsa-Putra argues that culture is a concept that leads to abroad phenomena and the complexities problems within. Likewise, Koentjaraningrat defines culture in an anthropological perspective, that culture is "the whole system of ideas, actions, and human creations in the context of community life which are taken into human possession by learning" (Koentjaraningrat 2002:180). This thought triggered Ahimsa-Putra's criticism towards Koentjaraningrat's theoretical thinking, especially those related to the formulation of cultural definition, dimensions, and elements.

In his writings, Ahimsa-Putra contains the division of cultural forms according to Koentjaraningrat, it is divided into three forms, namely (a) the ideal form of culture: a complex of ideas, notions, values, norms, rules, and so on; (b) a social system: a complex of patterned activities and actions of humans in society; and (c) physical culture: man-made material objects (Koentjaraningrat 2002:206). This theory was obtained by Koentjaraningrat from Honigmann (1959) so here he merely elaborated according to his perceptivity (see; Koentjaraningrat 2002:186-88). Ahimsa-Putra did not probe too much detail about the origin of the theory offered by Koentjaraningrat, so it seemed that the thoughts he was pouring out were purely Koentjaraningrat's thoughts - even though there were socio-cultural scientists who proposed these theoretical thoughts first. Nevertheless, Koentjaraningrat had been successful in acquaint theoretical and anthropological thoughts among Indonesian scholars.

Furthermore, Ahimsa-Putra points out Koentjaraningrat's claim about the universal nature of the existence of cultural elements which could be found in various cultures around the world. AhimsaPutra explained that the unity of the universal elements of culture was further considered as a system. The following is the classification of cultural elements proposed by Koentjaraningrat, divided into (a) language; (b) knowledge systems; (c) social organization; (d) live equipment systems and technology; (e) livelihood system; (f) religious system; and (g) arts (Koentjaraningrat 2002:203-04; 2005:81). According to Koentjaraningrat, each of these cultural elements is reflected in the three forms of culture, for example, in the element of the religious system it is reflected in the existence of a form of culture composed of (a) the idea of divinity - the ideal form (knowledge), (b) the tradition of religious ceremonies - the form of social systems (actions), and (c) material objects in the form of statues incarnated gods - forms of physical culture (material objects).

According to Ahimsa-Putra, Koentjaraningrat (1990) described the smaller elements conceivably possible to use while studying culture, namely cultural items and cultural traits. However, he did not explain the definition of both but gave an example as follows, the livelihood system can be subdivided into two elements, namely (a) farming livelihoods, hunting, etc. - elements of cultural items, and (b) farming livelihoods can be divided into different ways and equipment for tillage, planting, etc. - elements of cultural traits. Based on the implicit explanation, both cultural items and cultural traits are intended to further narrow the focus of cultural elements thus cultural studies can be more specific towards an element. 
Indonesian Journal of Social Sciences Volume 13 No. 02, July-December 2021, page 84-94

Based on the various scientific opinions stated above, the redefinition of culture was carried out by Ahimsa-Putra as a form of reflection on the interpretation of culture according to the context of the development of civilization. His presentation was very clear and detailed, not only trying to explore and criticizing the ideas that he considered less relevant and needed development, but Ahimsa-Putra also gave appreciation to Koentjaraningrat's scientific theories. Criticism begins with his disagreement with the definition of culture. According to Ahimsa-Putra, Koentjaraningrat's definition of culture is more sociological and less philosophical. According to him, Koentjaraningrat was misleading to stress the embodiment aspects of culture as a fundamental basis for the definition because it has only reached the empirical level. Second, he questioned the use of the word "form (wujud)" in "cultural forms" which he considered better to be used to express something concrete, not abstract. Third, Ahimsa-Putra takes an issue with the ambiguity of the use of the three cultural forms which seem to be separate from one another. Fourth, the confusion in the elements of culture, further Ahimsa-Putra gives an example of the inaccuracy of the elements of the livelihood system and the knowledge system. Fifth, he regretted the coverage of cultural elements that did not accommodate other socio-cultural phenomena such as the culture of medicine. Sixth, language is included in the classification of non-dimensional elements so that according to Ahimsa-Putra it limits anthropologists to explore understandings related to language and its relationship to social reality.

So far, I agree with Ahimsa-Putra's opinion, but there is a note that draws my attention to the sixth criticism, namely that in terms of positioning language in anthropology this may be different from the study of linguistics. If linguistics is based on the scientific exploration of existing languages, then anthropology is at least earlier in exploring the relationship of language, society, and culture which includes communicative practices and cognitive models of language and thought (Riley 2007:8, 11, 51). For example, ethnolinguistics plays a role in language writing in a culture that does not recognize writing or in a particular society (Koentjaraningrat 2002:14). While linguistics focuses on the development of linguistics in general and more technical. However, in practice, these two branches of knowledge contribute to each other.

While in his writings, Ahimsa-Putra also symbolizes humans as animals (animal symbolicum) as Ernst Cassirer (1945) expresses this perception. Ahimsa-Putra relates this view to the existence of signs and symbols in the scope of communication. The essence of culture is contrasted with nature by Ahimsa-Putra to ensure an explanation for something constructed and something that occurs naturally beyond human intervention. Furthermore, according to him, natural phenomena are considered cultural symptoms when they have turned into symbolic phenomena. Formulating the philosophical definition of culture is done by examining the relationship between humans and other living things. Humans have a culture, on this statement if many people agree, but the sentence uttered by AhimsaPutra "There is no animal on earth that can be said to have culture," I disagree. Other living things have a natural way of surviving in the process of natural selection. Although much debate about this among anthropologists, but the evidence showing alternative animal behavior as a reflection of culture cannot be ruled out. Primates such as capuchin monkeys, chimpanzees, and orangutans, as well as bird varieties such as crows, for example, have used natural technologies as these demonstrate the cognitive or instinctive intelligence of animals (Weir 2005:141-42; Kenward et al. 2005:121; Russon \& Begun 2004). Weir concludes the use of natural technology by animals involves nothing but cognitive processes in the genetic aspect and simple associative learning. So far, ethnography is still exclusive with the linkage of "cultural" elements in the perspective of the anthropocentric world with alternative approaches in genetics, ecology, and individual learning (Laland \& Janik 2006:543). I agree with Laland and Janik that culture is a source of adaptive behavior that not only allows humans to adapt to their environment but also for animals. Therefore, there is no impossibility how they protect themselves from each other even though with different cognitive capacities.

Ahimsa-Putra argues, dynamic changes tend to occur in human life, not animal life. However, the adjustment of humans to their physical environment indirectly illustrates how humans adopt the 
culture of other creatures in order to survive. Human adaptation is usually done through observation and imitation of thoughts, behaviors, signs, symbols, etc. All of this information is obtained through communication as outlined in the language. "Without language, there will be no social life," is a necessity which I think is right for Ahimsa-Putra to say. Language shows that humans are social creatures or zoon politicon according to Aristotle thus language becomes an important element in the existence of a culture. Through language, society grows and develops.

Language is a communication medium as it relates to signs and symbols thus the distribution of meaning becomes more explicit. Meaning in culture is known through symbolism or something symbolized - Ahimsa-Putra refers to White's opinion (1949) that meaning does not necessarily exist but is given by humans. Ahimsa-Putra presents a conflict about which came first, whether a symbol or a sign, and in the end, he argues that signs existed before symbols thereby "words" are not the smallest element in linguistics as expressed by de Saussure, but phonemes. Furthermore, de Saussure quoted by Ahimsa-Putra, divides the sign into two sides, namely the signified and signifier sides. According to Ahimsa-Putra's explanation, signs and symbols are two different things - signs are implicit while symbols are explicit - it means the meaning of signs is more difficult to recognize and realize than symbols. Ahimsa-Putra presents two different views on symbols and signs. The symbol, on the one hand, is considered as a form of sign and on the other hand, the sign is a form of symbol. I agree with Ahimsa-Putra on the former but on the latter, I dissented. Perhaps it is more appropriate to say that the sign is contained in the symbol because the sign is more abstract. A symbol is what contains a sign that is formed through a more complex cognitive construction process that results in the differentiation of meaning (Toren 2008:159). The symbol is the most appropriate sign to exemplify the decontextualized semantic meaning (Mertz 1985:2 referring to the work of Peirce (1974)). Ahimsa-Putra stated that there is no intrinsic relation between the symbol and its meaning because the meaning was proposed by humans. The existence of these signs and symbols is basically a trace of culture.

Meanwhile, according to Ahimsa-Putra, culture is "all the signs and symbols that humans acquire through the learning process in their lives as citizens, and which they use to build their world and adapt to it" (Ahimsa-Putra 2020:10). This view is more specific than the definition of culture put forward by both Koentjaraningrat and Djojodigoeno as the reference of his comparative review. Subsequently, he made sure of avoiding the potential for fallacy which lies behind his notion in redefining culture, which is marked by applying the following elements: (a) signs and symbols; (b) the learning process; (c) the lives of citizens, (d) used to build their world; and (e) adapt to it. The definition has at least accommodated the form, formation process, object and subject, function, and purpose of culture. Observation of socio-cultural phenomena generally refers to what has been, is, or will happen in human life and the environment. In many definitions of culture expressed by sociocultural scientists, the views of Ahimsa-Putra, Koentjaraningrat, and Kroeber's views have the same essence. According to Kroeber, culture is transmitted by social interactions wrapped in patterns or regularities of form, style, and significance so that culture embodies the values it wants to represent (Moore 2009:70). Moore further concludes Kroeber's simple definition that culture is learned, shared, patterned, and meaningful. 'Social'--both in the sense of an adjective and a noun--is the basis for the concept of culture because ontologically it shows an anthropocentric mindset. This legitimizes the view that culture is the result of the social construction of society.

The redefinition of culture proposed by Ahimsa-Putra seems to be strongly influenced by the view of structural anthropology pioneered by Claude Lévi-Strauss who adopted the concept of linguistics in his anthropological studies. In the view of structural anthropology, which is analyzed using structural phonology, it comes to the definition that culture is an apparatus or sign system as previously expressed by de Saussure and Jakobson (Ahimsa-Putra 2011:24). If this is reflected in his initiative to use the word "signs and symbols" in his proposed definition of culture. Ahimsa-Putra seems to desire to represent the existence of language as an inseparable element in culture - both verbally/non- 
Indonesian Journal of Social Sciences Volume 13 No. 02, July-December 2021, page 84-94

verbally and in writing/unwritten - as an instrument of communication in social interaction. Departing from signs and symbols, Ahimsa-Putra shows a representation of the philosophical roots of a culture. It has been realized together, through language, ideas even knowledge might be built and developed as far as it reaches a more complex order. This reason makes sense if it is related to Ahimsa-Putra's criticism of Koentjaraningrat about his inappropriate use of the embodiment aspect of a culture. Besides that, the point of culture is placed in a context of 'regularity' all at once ripen into a characteristic of culture. Ahimsa-Putra constructs a practical learning process that sets up the basis for the formation of repeated social behavior patterns. Malinowski described culture as an integrated part of adaptive responses (Moore 2009:145). Finally, the point used by Ahimsa-Putra in redefining culture is related to the 'function,' the existence of a culture is nothing but to adapt and develop.

Studying culture, cannot be separated from socio-cultural phenomena as it exists through human consciousness, Ahimsa-Putra cites Phillipson (1972). This awareness produces social reality due to it is shaped by language as it is understood to be social and intersubjective, added Ahimsa-Putra. Then, Ahimsa-Putra also includes a classification of cultural dimensions and elements. Applying the word "dimension" is aimed towards his disagreement previously with the use of the term "form or wujud" in the distinction of cultural forms presented by Koentjaraningrat. In my opinion, it is not a problem to apply those two terms, considering it correlates towards the same meaning of "aspects" of culture. The term wujud taken from Arabic contains different meanings. Most scientists even use it to present concrete things but wujud can also be interpreted "to make or find" (Dobie 2007:313), or cognitively this is more abstract because the idea is not necessarily contained in behavior. However, this understanding provides room to turn the intangibility into tangibility. Therefore, the word "wujud" can represent both concrete and abstract things such as ideas or knowledge.

Table 1.

Table of differences in form and dimensions of culture

\begin{tabular}{|c|c|c|c|}
\hline \multicolumn{2}{|c|}{ Koentjaraningrat } & \multicolumn{2}{|c|}{ Ahimsa-Putra } \\
\hline \multicolumn{2}{|c|}{ Form (Wujud) } & \multicolumn{2}{|c|}{ Dimension } \\
\hline $\begin{array}{l}\text { The ideal form of } \\
\text { culture }\end{array}$ & $\begin{array}{c}\text { A complex of ideas, } \\
\text { notions, values, } \\
\text { norms, rules, and so } \\
\text { on. }\end{array}$ & $\begin{array}{l}\text { Physical or material } \\
\text { dimension }\end{array}$ & $\begin{array}{l}\text { The result of patterns } \\
\text { of human behavior. }\end{array}$ \\
\hline Form of social system & $\begin{array}{c}\text { A complex of } \\
\text { patterned activities } \\
\text { and actions of humans } \\
\text { in society. }\end{array}$ & Behavioral dimension & $\begin{array}{l}\text { Human actions in } \\
\text { various activities. }\end{array}$ \\
\hline \multirow[t]{2}{*}{$\begin{array}{l}\text { Form of physical } \\
\text { culture }\end{array}$} & Man-made objects. & Linguistic dimension & $\begin{array}{c}\text { The sounds produced } \\
\text { by the human oral } \\
\text { cavity can be } \\
\text { considered as signs or } \\
\text { symbols. }\end{array}$ \\
\hline & & $\begin{array}{l}\text { Dimension of } \\
\text { knowledge }\end{array}$ & $\begin{array}{l}\text { The abstract ideas and } \\
\text { could only be realized } \\
\text { through lanquage. }\end{array}$ \\
\hline
\end{tabular}

Source: Koentjaraningrat 2002:206 and Ahimsa-Putra 2020:13-4

The dimensions of culture by Ahimsa-Putra are divided into four, namely (a) physical or material dimensions; (b) behavior; (c) language; and (d) knowledge based on its ontological review. While the 
elements of Koentjaraningrat culture were developed by Ahimsa-Putra - he divided them into ten elements (apparatus), namely (1) communication; (2) classification; (3) organization; (4) economy; (5) health; (6) belief; (7) preservation; (8) transportation; (9) games or entertainment; and (10) arts. Ahimsa-Putra provides a very interesting perspective when each set contains four cultural dimensions.

Cultural dimensions (aspects) division carried out by Ahimsa-Putra is not very significant due to neither his thoughts and Koentjaraningrat are actually very much alike, only expressed in different terms. However, the addition of this linguistic (kebahasaan) dimension is an interesting thing to review. Because the other dimensions already reflect what is understood as a subsystem, a set of variables that can be used to provide an explanation of how people understand culture (Kaplan \& Manners 2012:124). Language and culture have complex homologous relationships that influence each other (Krasniqi 2019:71). The unclear boundary line between language and culture consequently couldn't be able to position language as a subsystem. However, Ahimsa-Putra here attempts to place "linguistic (kebahasaan)" as a subsystem. In my opinion, this can be understood as long as the term 'linguistic' referred here is clearly and consistently distinguished from 'language'.

\section{Scheme 1.}
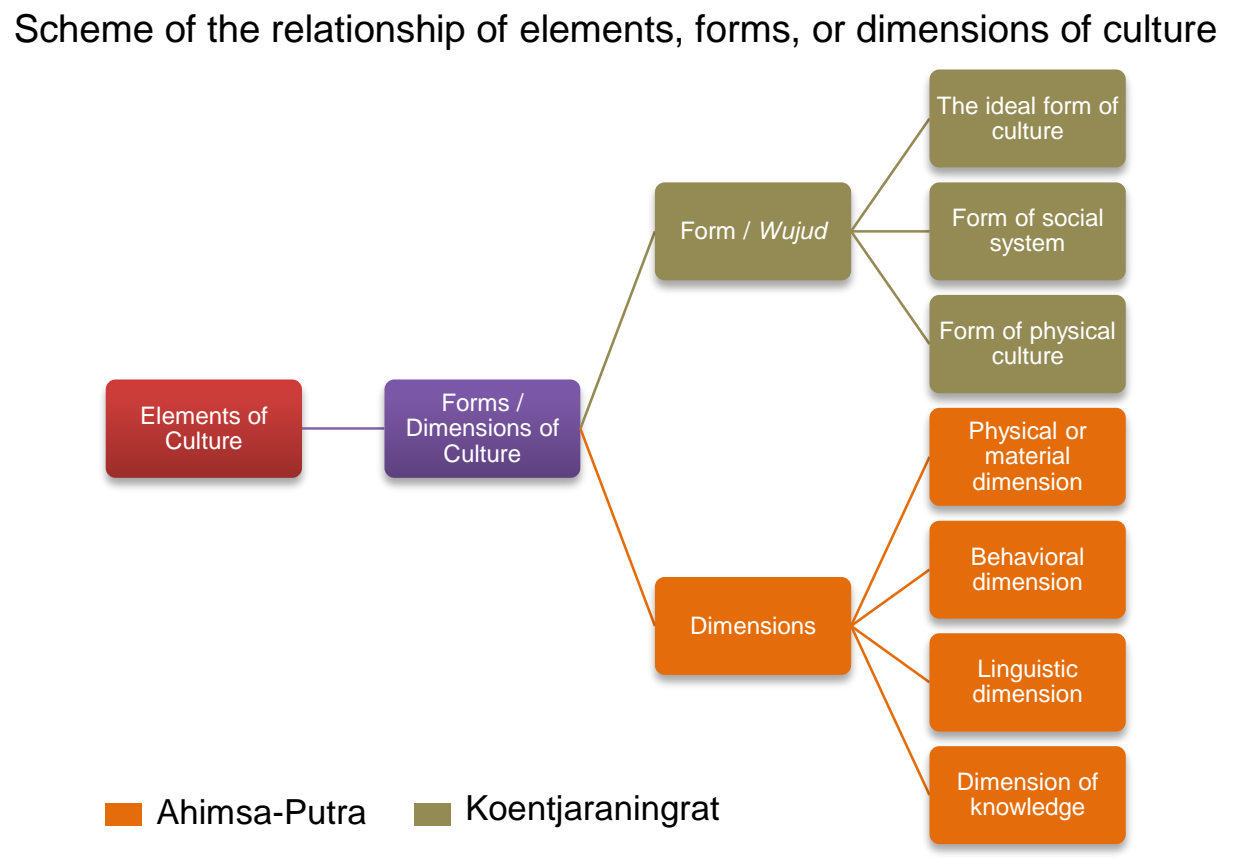

Source: Ahimsa-Putra 2020

The dichotomy above does not seem to accommodate the need for cultural research as a whole. Here I found the obscure terminologies of Ahimsa-Putra exerted in his writing. I was confused by the inconsistency of applying the word 'language (bahasa)' and 'linguistic (kebahasaan)' which eventually impacted his formulation of the cultural dimension. He heretofore had time to distinguish those two by applying the word "linguistic (kebahasaan)" but then he gave a slightly surprising statement when bringing up the word "language (bahasa)" within. Ahimsa-Putra (2020:14) stated ".... cannot be directly related to the knowledge dimension, except through the language dimension". His original statement in Indonesian: ".... tidak dapat berhubungan langsung dengan dimensi pengetahuan, kecuali dengan melalui dimensi bahasa". Is this writing just a minor error or unconsciousness that can be understood, but raises questions such as (a) why is it called the 
dimension of language is not linguistic even though Ahimsa-Putra's stance at the beginning has correctly referred to the definition of linguistic. According to Ahimsa-Putra, linguistic can be manifested through language due to its function as a communication tool, without language it is only considered a linguistic ability. Later on, it explicitly states in Indonesian: "wujud kebahasaan ini jangan dikacaukan atau disamakan dengan bahasa." (Ahimsa-Putra 2020:13); (b) should the word "dimension" in the "language dimension" be omitted; (c) does it implicitly mean that in the linguistic dimension there, is 'language,' or (d) is it equated between the two? Isn't that linguistic element contained in language, both verbal and non-verbal, which serves as a as instructions for using the correct language.

This confusion is at least partially represented by Ahimsa-Putra's answer in his supplementary notes. The linguistic aspect or dimension is transformed into an orality dimension which is considered more appropriate in accommodating hermeneutics related to language that appears in real terms such as spoken words or abstracts such as sounds. Regarding this error, in my opinion, it is more appropriate to use the linguistic dimension considering the orality dimension tends to limit the broad linguistic realm. Orality itself is a part of the language. Especially if Ahimsa-Putra's consideration of the empirical form of culture abides as 'interpreted sounds' - then what about signs or symbols that are not expressed by 'sound' but by writing, such as inscriptions. Thus, the linguistic dimension is more appropriate to use hence it contains sub-dimensions of orality and literacy. Orality and literacy are necessary for the evolution of consciousness (Ong 2002:171). It implies that society continues to develop thus the two aspects related to this language couldn't be ruled out.

Table 2.

Table of Ahimsa-Putra's cultural dimensions (aspects) and elements

\begin{tabular}{|c|c|c|c|c|}
\hline \multirow{2}{*}{$\begin{array}{l}\text { Cultural } \\
\text { Elements }\end{array}$} & \multicolumn{4}{|c|}{ Dimension } \\
\hline & Knowledge & Language & Behavior & Material \\
\hline Communication & $\begin{array}{l}\text { Grammar, } \\
\text { semantics }\end{array}$ & $\begin{array}{l}\text { Communication } \\
\text { terms }\end{array}$ & $\begin{array}{l}\text { Chatting, talking, } \\
\text { calling }\end{array}$ & $\begin{array}{c}\text { Telephone, } \\
\text { television, radio, } \\
\text { internet }\end{array}$ \\
\hline Classification & $\begin{array}{l}\text { Counting, } \\
\text { mathematics }\end{array}$ & Calculation terms & $\begin{array}{l}\text { Calculation } \\
\text { activities }\end{array}$ & $\begin{array}{l}\text { Abacus, computer, } \\
\text { calculator }\end{array}$ \\
\hline Organization & $\begin{array}{l}\text { Values, norms, } \\
\text { rules }\end{array}$ & $\begin{array}{l}\text { Terms, } \\
\text { organizational } \\
\text { discourses }\end{array}$ & $\begin{array}{l}\text { Kinship, } \\
\text { associations }\end{array}$ & $\begin{array}{l}\text { Village halls, } \\
\text { houses, } \\
\text { settlements }\end{array}$ \\
\hline Economy & $\begin{array}{l}\text { Knowledge of } \\
\text { flora, fauna, soil, } \\
\text { water }\end{array}$ & $\begin{array}{c}\text { Discourse terms } \\
\text { about flora, fauna, } \\
\text { nature }\end{array}$ & $\begin{array}{c}\text { Hunting, } \\
\text { gathering, } \\
\text { farming, raising } \\
\text { livestock }\end{array}$ & $\begin{array}{l}\text { Hunting, } \\
\text { gathering, farming, } \\
\text { raising livestock } \\
\text { equipment }\end{array}$ \\
\hline Health & $\begin{array}{l}\text { Knowledge of } \\
\text { health, illness, } \\
\text { medicine }\end{array}$ & $\begin{array}{l}\text { Terms, health } \\
\text { discourse }\end{array}$ & Medicine & $\begin{array}{l}\text { Medicine, medical } \\
\text { equipment }\end{array}$ \\
\hline Belief & $\begin{array}{c}\text { Beliefs about the } \\
\text { unseen world }\end{array}$ & $\begin{array}{l}\text { Terms, religious } \\
\text { discourses }\end{array}$ & $\begin{array}{l}\text { Rituals, } \\
\text { ceremonies }\end{array}$ & $\begin{array}{l}\text { Worship tools, } \\
\text { houses of worship }\end{array}$ \\
\hline Preservation & $\begin{array}{l}\text { Knowledge, } \\
\text { values, norms, } \\
\text { rules }\end{array}$ & $\begin{array}{l}\text { Terms, } \\
\text { preservation } \\
\text { discourse }\end{array}$ & $\begin{array}{l}\text { Teaching, } \\
\text { preservation, } \\
\text { learning }\end{array}$ & $\begin{array}{c}\text { Books, pencils, } \\
\text { schools, museums }\end{array}$ \\
\hline
\end{tabular}




\begin{tabular}{|c|c|c|c|c|}
\hline \multirow{2}{*}{$\begin{array}{l}\text { Cultural } \\
\text { Elements }\end{array}$} & \multicolumn{4}{|c|}{ Dimension } \\
\hline & Knowledge & Language & Behavior & Material \\
\hline Transportation & $\begin{array}{l}\text { Knowledge of } \\
\text { means of } \\
\text { transportation }\end{array}$ & $\begin{array}{l}\text { Terms, } \\
\text { discourses on } \\
\text { transportation }\end{array}$ & $\begin{array}{l}\text { Transportation } \\
\text { activities }\end{array}$ & $\begin{array}{l}\text { Bicycles, trains, } \\
\text { cars, planes }\end{array}$ \\
\hline Game & $\begin{array}{c}\text { Philosophy of the } \\
\text { game, values, } \\
\text { rules }\end{array}$ & $\begin{array}{l}\text { Discourse about } \\
\text { the game, sports }\end{array}$ & Sports, games & $\begin{array}{l}\text { Sports equipment, } \\
\text { game tools }\end{array}$ \\
\hline Art & $\begin{array}{l}\text { Knowledge of } \\
\text { beauty }\end{array}$ & $\begin{array}{l}\text { Terms, discourse } \\
\text { on beauty }\end{array}$ & $\begin{array}{c}\text { Dancing, } \\
\text { singing, painting, } \\
\text { carving }\end{array}$ & $\begin{array}{c}\text { Dance equipment, } \\
\text { painting, carving, } \\
\text { music }\end{array}$ \\
\hline
\end{tabular}

Source: Ahimsa-Putra 2020:18

My concern lies in Ahimsa-Putra's correction of the "language dimension" he wrote on his table with the "orality dimension" he added recently. This change raises ambiguity about the relationship between these dimensions and the cultural elements he has defined. Alas, he has not provided a further explanation regarding this matter.

Furthermore, I move on to the cultural element. The Table 2 has detailed the intersection of cultural dimensions and cultural elements proposed by Ahimsa-Putra. He mentions the function of each element, namely:

Table 3.

Table of functions of Ahimsa-Putra cultural elements

\begin{tabular}{ll}
\hline Cultural Elements & Function to Solve Problems \\
\hline Communication & Relationship among individuals \\
Classification & Orderliness \\
Organization & Cooperation and social reproduction \\
Economy & Scarcity of food and clothing \\
Health & Biological reproduction \\
Belief & Helplessness \\
Preservation & Loss or extinction \\
Transportation & Displacement \\
Game & Boredom \\
Art & Expression of feelings \\
\hline
\end{tabular}

After discussing the cultural dimension, I move on to the cultural element. From the overall description of the elements of culture by Ahimsa-Putra. I have some opinions on that. First, in the description, there is no element of legal instruments. Law should be included as one of the elements of culture, it can be called an element of legal instruments. One thing that is no less important for an anthropologist to observe is "law" as I believe it always exists in social life, whether it is only in the form of conventions to written regulations that are imperative (dwigendrecht). Its existence is intended so that each individual behaves according to the values and norms expected by the 
Indonesian Journal of Social Sciences Volume 13 No. 02, July-December 2021, page 84-94

community with the aim of creating social order. Order and law must be maintained together inasmuch as 'cooperation' is the essence of every cultural achievement, therefore in every community, there must be arrangements for customary, ethical, and legal sanctions (Malinowski 1961:37). This element of law cannot be immediately illustrated by the existence of elements of organizational or preservation equipment, for example, because in essence, the law has its own uniqueness which guides the behavior of every community member (Anaya 2005:128). Related to customary law, for example, its existence at least refers to the material element shown from the uniformity of behavior and the psychological element (opinio juris) which describes the existence of self-awareness to adapt to socially expected behavior patterns. Law enforcement agencies are also present in order to provide legitimacy to the law so that the community's agreement on the values and norms set is binding and results in individuals and society having moral and social responsibilities. None of these legal instruments can be studied from the four dimensions previously stated by Ahimsa-Putra. Details of this matter presented in the Table 4.

Second, the "organization" term on the elements of the organizational apparatus in the description of Ahimsa-Putra's cultural elements does not seem appropriate considering the term organization is more emphasized on concrete entities. The term institution is apt to apply due to its spacious domain includes abstract entities. Institutions are shaped by culture. Alesina and Giuliano cite Greif's opinion that an institution is a system of (man-made) social factors - which are exogenous to each affected individual - which together produce behavioral regularities (Alesina \& Giuliano 2015:901-02). Furthermore, the existing boundaries include rules, values, and norms (North 1990:4; Greif 2006:38283). For example, the family is more accurately referred to not as an organization but an institution. Afterward, if there's a correction on the element's terminology, it will sound better to switch it by utilizing the "institution" term.

Third, the elements of the game (entertainment) and art by Ahimsa-Putra are distinguished only based on the classification of art and non-art. Games should not be equated with entertainment if they are based solely on reasons to overcome boredom. The elements of the actual art equipment also contain "entertainment" within. Fine arts, performances, motion, literature, and music are not only a medium for talented people to express themselves, but there are works that can be produced that can be enjoyed as entertainment for both performers and art connoisseurs. If it was desired to rigidly differentiate between games and art, then the term "entertainment" does not need to be applied as an alternative word in referring to the elements of game apparatus.

Table 4.

Table of adapted Ahimsa-Putra's cultural dimensions (aspects) and elements

\begin{tabular}{|c|c|c|c|c|}
\hline \multirow{2}{*}{$\begin{array}{l}\text { Cultural } \\
\text { Elements }\end{array}$} & \multicolumn{4}{|c|}{ Dimension } \\
\hline & Knowledge & Linguistic & Behavior & Material \\
\hline Communication & $\begin{array}{l}\text { Grammar, } \\
\text { semantics }\end{array}$ & $\begin{array}{c}\text { Communication } \\
\text { terms }\end{array}$ & $\begin{array}{l}\text { Chatting, talking, } \\
\text { calling }\end{array}$ & $\begin{array}{c}\text { Telephone, } \\
\text { television, radio, } \\
\text { internet }\end{array}$ \\
\hline Classification & $\begin{array}{l}\text { Counting, } \\
\text { mathematics }\end{array}$ & Calculation terms & $\begin{array}{l}\text { Calculation } \\
\text { activities }\end{array}$ & $\begin{array}{l}\text { Abacus, computer } \\
\text { calculator }\end{array}$ \\
\hline Institution & $\begin{array}{l}\text { Values, norms, } \\
\text { rules }\end{array}$ & $\begin{array}{c}\text { Terms, } \\
\text { organizational } \\
\text { discourses }\end{array}$ & $\begin{array}{l}\text { Kinship, } \\
\text { associations }\end{array}$ & $\begin{array}{l}\text { Village halls, } \\
\text { houses, } \\
\text { settlements }\end{array}$ \\
\hline Economy & $\begin{array}{l}\text { Knowledge of } \\
\text { flora, fauna, soil, } \\
\text { water }\end{array}$ & $\begin{array}{c}\text { Discourse terms } \\
\text { about flora, fauna, } \\
\text { nature }\end{array}$ & $\begin{array}{c}\text { Hunting, } \\
\text { gathering, } \\
\text { farming, raising }\end{array}$ & $\begin{array}{l}\text { Hunting, } \\
\text { gathering, farming } \\
\text { raising livestock }\end{array}$ \\
\hline
\end{tabular}




\begin{tabular}{|c|c|c|c|c|}
\hline \multirow{2}{*}{$\begin{array}{l}\text { Cultural } \\
\text { Elements }\end{array}$} & \multicolumn{4}{|c|}{ Dimension } \\
\hline & Knowledge & Linguistic & Behavior & Material \\
\hline & & & livestock & equipment \\
\hline Health & $\begin{array}{l}\text { Knowledge of } \\
\text { health, illness, } \\
\text { medicine }\end{array}$ & $\begin{array}{l}\text { Terms, health } \\
\text { discourse }\end{array}$ & Medicine & $\begin{array}{l}\text { Medicine, medical } \\
\text { equipment }\end{array}$ \\
\hline Belief & $\begin{array}{l}\text { Beliefs about the } \\
\text { unseen world }\end{array}$ & $\begin{array}{l}\text { Terms, religious } \\
\text { discourses }\end{array}$ & $\begin{array}{l}\text { Rituals, } \\
\text { ceremonies }\end{array}$ & $\begin{array}{l}\text { Worship tools, } \\
\text { houses of worship }\end{array}$ \\
\hline Preservation & $\begin{array}{c}\text { Knowledge, } \\
\text { values, norms, } \\
\text { rules }\end{array}$ & $\begin{array}{l}\text { Terms, } \\
\text { preservation } \\
\text { discourse }\end{array}$ & $\begin{array}{l}\text { Teaching, } \\
\text { preservation, } \\
\text { learning }\end{array}$ & $\begin{array}{l}\text { Books, pencils, } \\
\text { schools, museums }\end{array}$ \\
\hline Transportation & $\begin{array}{l}\text { Knowledge of } \\
\text { means of } \\
\text { transportation }\end{array}$ & $\begin{array}{c}\text { Terms, } \\
\text { discourses on } \\
\text { transportation }\end{array}$ & $\begin{array}{l}\text { Transportation } \\
\text { activities }\end{array}$ & $\begin{array}{l}\text { Bicycles, trains, } \\
\text { cars, planes }\end{array}$ \\
\hline Game & $\begin{array}{c}\text { Philosophy of the } \\
\text { game, values, } \\
\text { rules }\end{array}$ & $\begin{array}{l}\text { Discourse about } \\
\text { the game, sports }\end{array}$ & Sports, games & $\begin{array}{l}\text { Sports equipment, } \\
\text { game tools }\end{array}$ \\
\hline Art & $\begin{array}{l}\text { Knowledge of } \\
\text { beauty }\end{array}$ & $\begin{array}{l}\text { Terms, discourse } \\
\text { on beauty }\end{array}$ & $\begin{array}{c}\text { Dancing, } \\
\text { singing, painting, } \\
\text { carving }\end{array}$ & $\begin{array}{c}\text { Dance equipment, } \\
\text { painting, carving, } \\
\text { music }\end{array}$ \\
\hline Law & $\begin{array}{l}\text { Values, norms, } \\
\text { rights and } \\
\text { obligations, rules }\end{array}$ & $\begin{array}{c}\text { Terms, } \\
\text { discourses on law }\end{array}$ & $\begin{array}{l}\text { Obeying } \\
\text { regulations, } \\
\text { ceremonies, } \\
\text { convening } \\
\text { statutory }\end{array}$ & $\begin{array}{c}\text { Regulations, } \\
\text { written customary } \\
\text { regulations, } \\
\text { judicial institutions }\end{array}$ \\
\hline
\end{tabular}

Source: Refers to the thoughts of Ahimsa-Putra

\section{Conclusion}

Overall, Ahimsa-Putra's writings are very constructive and systematic, making it easier for me to follow his line of thought. Nevertheless, in his thinking, there are several things that have not been consistently stated, including the implications of changes in one of the cultural dimensions towards the elements of culture that he has determined. Most of the criticisms that I have made above are related to terminology, disagreements with supporting arguments, and things that have not been included in Ahimsa-Putra's philosophical writing. I interpret these criticisms as suggestions as transparency in information requires the academic community to contribute to the development of science. It was realized from the start, Ahimsa-Putra's writings have opened up insight and philosophical thoughts about 'culture' which have developed to be more specific than previous thoughts that seem more general. His theory is philosophical and progressive and yet the formulation of the dimensions and elements of culture needs a little refinement. Thus, the theory he produces is still quite relevant to be imposed as a basic examination of a socio-cultural phenomenon today. 


\section{References}

Ahimsa-Putra HS (2011) Bahasa sebagai model studi kebudayaan di Indonesia - Antropologi struktural di Indonesia. Masyarakat Indonesia 37 (1):1-33.

Ahimsa-Putra HS (2020) Mendefinisikan Kembali Kebudayaan. In: Lembaran Antropologi Budaya 2 (2):2-25,46.

Alesina A \& Giuliano P (2015) Culture and institutions. Journal of Economic Literature 53 (4):898944.

Dobie RJ (2007) The Phenomenology of Wujud in the Thought of Ibn Al-'Arabi. In: Tymieniecka AT. Timing and Temporality in Islamic Philosophy and Phenomenology of Life. Islamic Philosophy and Occidental Phenomenology in Dialogue, Volume 3. Springer, Dordrecht. 313322.

Greif A (2006) Institutions and the Path to the Modern Economy: Lessons from Medieval Trade. Cambridge dan New York: Cambridge University Press.

Kaplan D \& Manners AA (2012) Teori Budaya. Yogyakarta: Pustaka Pelajar.

Kenward B, Weir AAS, Rutz C, \& Kacelnik A (2005) Tool manufacture by naive juvenile crows. Nature 433:121.

Koentjaraningrat (2002) Pengantar Ilmu Antropologi. Jakarta: Rineka Cipta.

Koentjaraningrat (2005) Pengantar Antropologi I. Jakarta: Rineka Cipta.

Krasniqi K (2019) The relation between language and culture (Case study Albanian Language). Linguistics and Literature Studies 7 (2):71-74.

Laland KN \& Janik VM (2006) The animal cultures debate. Trends in Ecology and Evolution 21 (10):542-547.

Lauer RH (1973) Temporality and social change: the case of 19th Century China and Japan. The Sociological Quarterly 14:451-464.

Malinowski B (1961) A Scientific Theory of Culture and Other Essays. New York: Oxford University Press.

Mertz E (1985) Beyond symbolic anthropology: introducing semiotic mediation. Semiotic Mediation:1-19.

Moore JD (2009) Visions of Culture: An Introduction to Anthropological Theories and Theorists. Lanham: AltaMira Press.

North DC (1990) Institutions, Institutional Change and Economic Performance. New York: Cambridge University Press.

Ong WJ (2002) Orality and Literacy: The Technologizing of the Word. London dan New York: Routledge.

Pardimin, Supriyoko K, Ghozali I, Prihatni Y, Hadi S, Setawan AD, \& Wardani K (2018) Kebijakan Pelestarian dan Pengembangan Kebudayaan. Universitas Sarjanawiyata Tamansiswa Yogyakarta.

Riley P (2007) Language, Culture and ldentity An Ethnolinguistic Perspective. London: Continuum.

Russon AE \& Begun DR (2004) The Evolution of Thought: Evolutionary Origins of Great Ape Intelligence. Cambridge: Cambridge University Press.

Toren C (2008) Sign into Symbol, Symbol as Sign: Cognitive Aspects of a Social Process. In: P Boyer (ed). Cognitive Aspects of Religious Symbolism. New York: Cambridge University Press. 147-164.

Weir AAS (2005) Cognitive Psychology of Tool Use in New Caledonian Crows (Corvus moneduloides). Dissertation, University of Oxford. 